\title{
Validity of Washburn's equation in sericin treated polyester fabric
}

\section{Valabilitatea ecuației lui Washburn în cazul țesăturii din poliester tratate cu sericină}

Aplicarea sericinei pe țesăturile de poliester și bumbac aduce avantaje, prin faptul că materialele devin mai hidrofile și sunt capabile să confere un efect antimicrobian. De asemenea, materialele pot fi vopsite utilizând coloranți reactivi. S-a efectuat o analiză foarte amănunțită cu privire la aplicarea sericinei pe țesăturile din poliester și bumbac. Higroscopicitatea țesăturilor tratate a fost studiată și s-a demonstrat că a existat o îmbunătățire. O analiză detaliată a studiului este justificată în ceea ce privește higroscopicitatea, deoarece analiza efectuată a fost limitată. În acest studiu, a fost necesară validarea ecuației lui Washburn, care constituie o componentă importantă a cineticii higroscopicității. Este studiată valabilitatea ecuației lui Washburn pentru un set de date privind higroscopicitatea țesăturilor din poliester tratate cu sericină. Stratul de poliester netratat și cel tratat cu sodă caustică și plasmă, urmat de tratamentul cu sericină utilizând DMDHEU și glutaraldehida, a fost prelevat pentru studiile privind higroscopicitatea. Au fost utilizate două modele. Din analiza gradienților, s-a constatat că este utilizată ecuația lui Washburn.

Cuvinte-cheie: substanțe alcaline, intercept, tratament cu plasmă, gradient, higroscopicitate

\section{Validity of Washburn's equation in sericin treated polyester fabric}

Application of sericin to polyester and cotton fabrics will bring about a number of advantages in that the materials become hydrophilic and are capable of imparting antimicrobial effect. Also, the materials can be dyed using reactive dyes. A considerable amount of work has been carried out on the application of sericin to polyester and cotton fabrics. Wickability of treated fabrics has been studied and it was demonstrated that there was an improvement. A detailed analysis of study is warranted on wickability as the work done on it was scant. It is necessary to validate Washburn's equation which constitutes an important component of kinetics of wicking in this paper. The validity of Washburn's equation for a set of data on wickability of sericin treated polyester fabrics is studied. Untreated polyester fabric and treated with caustic soda and plasma followed by sericin treatment using DMDHEU and Glutaraldehyde were taken for wicking studies. Two models were used. From the slopes it is found that Washburn's equation is followed.

Keywords: alkali, intercept, plasma treatment, slope, wickability

\section{INTRODUCTION}

Wickability of fabrics has become an important test as it discloses information on comfort, dyeability and usefulness as a sportswear. A number of papers on the wickability of yarns and fabrics have been published and reviews have appeared [1]. The role of water in transporting moisture has been appreciated for a very long time. A considerable amount of work has been done on the application of sericin to polyester and cotton fabrics with a view to conferring antimicrobial property to them [2-4]. From the papers published it is found that wickability test, although was performed on the fabrics, has not been studied in detail.

Wicking is the spontaneous transport of a liquid driven into a porous system by a capillary force [5]. Wicking height is proportional to root of time.

Lucas-Washburn equation, which is a very popular one, includes properties such as surface tension, radius of the capillary, contact angle and viscosity of the liquid which has been used to study wickability. It is reported that the weft density pore size and the arrangement of void spaces in fabric have a significant effect on the wicking performance [6]. It is also reported that the motion of liquid in the void spaces between fibers in a yarn impacts the mechanism of fabric wicking critically [7]. It is found that the rate of movement of liquid is governed by the fibre arrangement in yarn which control the capillary size and continuity [8].

Validity of Washburn's equation can be checked by two models, namely

$$
\begin{gathered}
h^{2}=c^{2} t \text { or } h=c \sqrt{ } t \\
h=c^{\prime} t^{k}
\end{gathered}
$$

Where $h$ is wicking height, $t$ - time and $k$ - time exponent, $c$ and $c$ ' are constants.

In this communication, the wickability of sericin treated polyester fabrics is dealt with. Although some data on wickability have been provided, they were not examined in detail. The applicability of Washburn's equation is discussed for a series of polyester fabrics that have been treated with sericin.

\section{MATERIALS AND METHODS}

Sericin was obtained from CSTRI Bangalore. Polyester fabric with plain weave having the specification of $133 \mathrm{~g} / \mathrm{m}^{2}$ weight with 55 ends per $\mathrm{cm}$ and 33 picks per $\mathrm{cm}$ was used for the study. 


\section{Modification of polyester fabric}

Polyester fabric sample was scoured to remove any impurities and it was pretreated with alkali $1 \mathrm{M}(40 \mathrm{~g} / \mathrm{l})$ $\mathrm{NaoH}$ at $80^{\circ} \mathrm{C}$ for 45 min with 1:100 material to liquor ratio to create functional groups on its surface, before applying sericin to the fabrics.

\section{Application of sericin}

Sericin was applied on modified polyester fabric with and without the use of a crosslinking agent.

$20 \mathrm{~g} / \mathrm{l}$ of sericin solution was used. Alkali treated fabric were padded with the sericin solution in a laboratory padding mangle by a 2 dip 2 nip process. The padded fabric was dried at $80^{\circ} \mathrm{C}$ for 3 min and cured at $130^{\circ} \mathrm{C}$ for $2 \mathrm{~min}$. Cured samples were then washed and dried. Glutaraldehyde was used as a crosslinking agent to attach sericin to alkali modified polyester.

\section{Plasma treated with DMDHEU}

The polyester fabric was prepared in the required dimension of $54 \times 54 \mathrm{~cm}$ and weighed. This fabric was clamped to the frame and inserted in the plasma chamber between the two plates and pressure in the chamber was brought to 0 bar then the oxygen gas was passed to the chamber with the flow rate of 2 bar pressure. Initially the top side of the fabric was exposed to the plasma current $1.06 \mathrm{amp}$, plasma voltage 350 volt at temperature $29^{\circ} \mathrm{C}$ this was continued for $5 \mathrm{~min}$. Then the bottom side of the fabric was exposed to the plasma current 1.53 amps, plasma voltage 300 volt at a temperature of $29^{\circ} \mathrm{C}$ for $5 \mathrm{~min}$. After the process, the fabric was weighed again to determine the weight loss percentage.

The plasma treated fabric was then wetted in water along with Turkey Red Oil $2 \mathrm{~g} / \mathrm{l}$ and immersed in the prepared solution (sericin 25\% (owf) and Dimethylol Dihydroxy Ethylene Urea 150\% (owf), polyethylene emulsion $2 \mathrm{~g} / \mathrm{l}$ based on weight of the sample) for dipping process and was carried out using material-toliquor ratio of 1:9. This fabric was then padded in the 2dip-2nip padding mangles and curing process carried at the temperature of $140^{\circ} \mathrm{C}$ for $3 \mathrm{~min}$. Plasma treatment changes the surface properties of the fabric [9].

Plasma treated with Glutaraldehyde (GA)

The required dimension of the plasma treated fabric was weighed and the fabric was wetted in water along with wetting agent (TRO) and then treated with the solution of Sericin 25\% (owf), GA $20 \mathrm{~g} / \mathrm{l}$, magnesium chloride $10 \mathrm{~g} / \mathrm{l}$ and acetic acid $1.0 \mathrm{ml} / \mathrm{l}$ using material-to-liquor ratio of $1: 9$. The above procedure was followed for both padding and curing.

\section{Alkali treatment with DMDHEU and Glutaraldehyde}

The same untreated polyester fabric was treated with $15 \% \mathrm{NaOH}$ (owf) with the material-to-liquor ratio kept at $1: 40$, at $60^{\circ} \mathrm{C}$ for $30 \mathrm{~min}$. This alkaline treated polyester fabric was then treated with sericin, Glutaraldehyde, magnesium chloride and acetic acid and sericin, DMDHEU, polyethylene emulsion combination as in the same manner above and then padded and then cured.

\section{Untreated polyester with DMDHEU and Glutaraldehyde}

Untreated polyester fabric was directly treated with DMDHEU with other chemicals and Glutaraldehyde with the above mentioned chemicals. Drying and curing were carried out at $140^{\circ} \mathrm{C}$ for $3 \mathrm{~min}$.

\section{Experimental}

In this study, seven samples of polyester fabric such as polyester fabric treated with alkali (PA), untreated polyester treated with sericin and Glutaraldehyde (USG), polyester fabric with sericin and DMDHEU (USD), Polyester fabric treated with alkali followed with Sericin and Glutaraldehyde (ASG), polyester fabric treated with alkaline followed with sericin and DMDHEU (ASD), Polyester fabric treated with plasma followed with sericin and Glutaraldehyde (PSG), Polyester fabric treated with plasma followed with sericin and DMDHEU (PSD). Details of the polyester fabrics used are given in table 1 .

\begin{tabular}{|c|c|c|c|c|c|}
\hline \multicolumn{7}{|c|}{ Table 1} \\
\hline \multicolumn{2}{|c|}{ PEOMETRICAL PROPERTIES OF UNTREATED AND TREATED POLYESTER FABRIC } \\
\hline S.No. & Ends/cm & Picks/ cm & GSM & Thickness (mm) \\
\hline 1 & Polyester fabric treated with alkali (PA) & 55 & 33 & 133 & 0.32 \\
\hline 2 & $\begin{array}{c}\text { Untreated Polyester fabric with sericin and } \\
\text { DMDHEU (USD) }\end{array}$ & 54 & 32 & 134 & 0.31 \\
\hline 3 & $\begin{array}{c}\text { Untreated polyester fabric with sericin and } \\
\text { glutaraldehyde (USG) }\end{array}$ & 55 & 34 & 135 & 0.32 \\
\hline 4 & $\begin{array}{c}\text { Alkali treated polyester fabric with sericin and } \\
\text { DMDHEU (ASD) }\end{array}$ & 54 & 33 & 137 & 0.33 \\
\hline 5 & $\begin{array}{c}\text { Alkali treated polyester fabric with sericin and } \\
\text { glutaraldehyde (ASG) }\end{array}$ & 55 & 34 & 138 & 0.32 \\
\hline 6 & $\begin{array}{c}\text { Plasma treated polyester fabric with sericin and } \\
\text { DMDHEU (PSD) }\end{array}$ & 54 & 33 & 131 & 0.32 \\
\hline 7 & $\begin{array}{c}\text { Plasma treated polyester fabric with sericin and } \\
\text { glutaraldehyde (PSG) }\end{array}$ & 54 & 33 & 133 & 0.32 \\
\hline
\end{tabular}




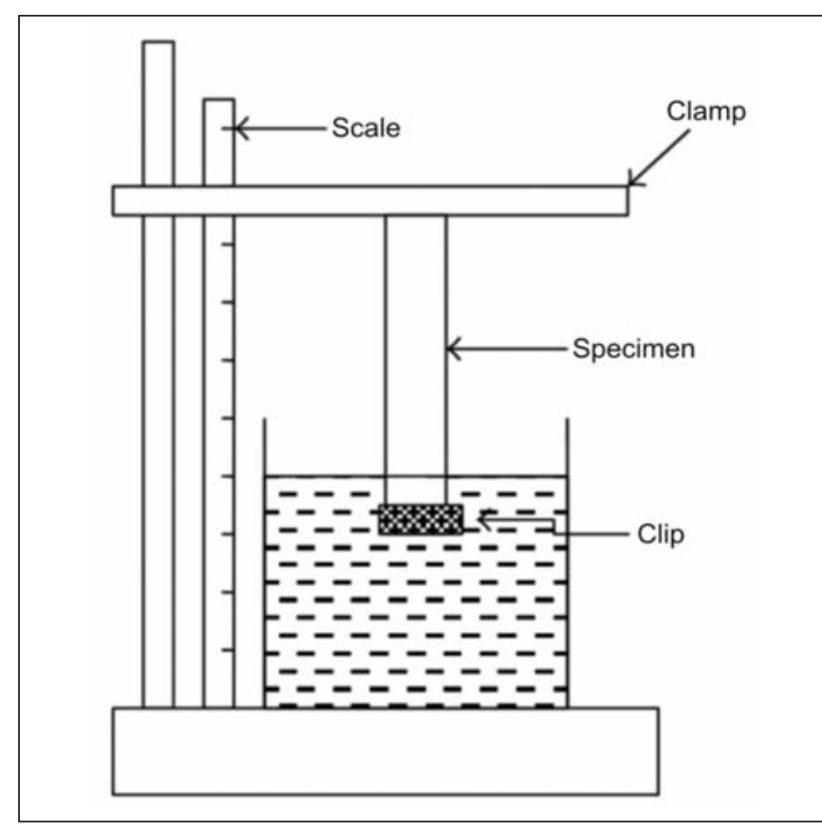

Fig. 1. Wicking test instrument

\section{Determination of Wickability of treated and untreated fabrics}

Wickability was studied by using vertical wicking method (DIN 53924 standard) as shown in figure 1.

\section{RESULTS AND DISCUSSION}

By plotting $h^{2}$ against $t$ and using regression model passing through origin it will be possible to obtain values of $K$ and check the applicability of Washburn's equation.

The evaluation of the $h^{2}$ as a function of time is determined for given times in the region of $0-600 \mathrm{~s}$ and the slopes are given in table 2. The curve obtained is linear and the experimental values lead to a linear regression coefficient of $R^{2}$ exceeding 0.99 . It is necessary to get a correlation coefficient of more than
0.99 , as only then will the Lucas Washburn's equation is followed.

The results of the wicking test are shown in tables 2 and 3.

\section{Model A}

Plotting height in $\mathrm{cm}^{2}$ against the time sec gives the following values which are given in table 2 .

Regression analysis has been done to get slope and intercept.

\section{Model B}

Values of slopes and intercepts are given in table 3 , following model $h=c^{\prime} t^{k}$.

There are two models which are used to find out the validity of Washburn's equation. The first model is

$$
\begin{gathered}
h^{2}=c^{2} t \text { or } h=c \sqrt{ } t \\
h=c^{\prime} t^{k}
\end{gathered}
$$

Where $h$ is wicking height in $\mathrm{cm}$ and $t-$ time in second. By plotting $h^{2}$ against $t$ and using regression model passing through origin it will be possible to obtain values of $k$ and check applicability of Washburn's equation. Values are shown in table 2.

The second model $\mathrm{B}$ is $h=c^{\prime} t^{k}$. This was proposed by Laughlin et al. [10] who suggested the following equation and Deboer [11] has also used this equation. It is interesting to note that Deboer [11] has not referred to Laughlin etals [10] paper in his study. By taking logarithm on both sides

$$
\ln (h)=k \ln (t)+\ln \left(c^{\prime}\right)
$$

This model has been used by Nyoni [12] and Zhuang et al. [13] in their studies.

Table 3 gives the results, in this equation, there are strange units $\ln \left(c^{\prime}\right)$ of $k$ and $c$ parameters. $c^{\prime}$ is not intercept but equal to value of $\ln (h)$ for time $t=1$. When $h=0, t=0$ and this leads to difficulties because $\ln (0)$ is minus infinity. Hence, while in $X$-axis the curve starts from zero, in Y-axis a finite value is

\begin{tabular}{|c|c|c|c|c|c|c|c|}
\hline \multicolumn{8}{|c|}{ VALUES OF THE TIME EXPONENT USING MODEL $h=c^{\prime} t^{k}$} \\
\hline $\begin{array}{l}\text { Time } \\
\text { (Sec) }\end{array}$ & $\begin{array}{c}\mathrm{PA} \\
\text { (cm) }\end{array}$ & $\begin{array}{l}\text { USD } \\
\text { (cm) }\end{array}$ & $\begin{array}{l}\text { USG } \\
\text { (cm) }\end{array}$ & $\begin{array}{l}\text { ASD } \\
\text { (cm) }\end{array}$ & $\begin{array}{l}\text { ASG } \\
\text { (cm) }\end{array}$ & $\begin{array}{l}\text { PSD } \\
\text { (cm) }\end{array}$ & $\begin{array}{l}\text { PSG } \\
\text { (cm) }\end{array}$ \\
\hline Slope (cm/min) & 0.83 & 0.53 & 0.52 & 0.43 & 0.48 & 0.47 & 0.49 \\
\hline Intercept & -3.93 & -1.57 & -1.61 & -1.05 & -1.27 & -1.37 & -1.38 \\
\hline $\mathrm{R}^{2}$ & 0.98 & 0.98 & 0.99 & 0.99 & 0.99 & 0.99 & 0.99 \\
\hline
\end{tabular}

\begin{tabular}{|c|c|c|c|c|c|c|c|}
\hline \multicolumn{8}{|c|}{ VALUES OF THE SLOPE AND INTERCEPT USING MODEL $\mathrm{h}^{2}=\mathrm{c}^{2} \mathrm{t}$} \\
\hline $\begin{array}{c}\text { Time } \\
(\mathbf{s e c})\end{array}$ & $\begin{array}{c}\text { UT } \\
(\mathbf{c m})\end{array}$ & $\begin{array}{l}\text { USD } \\
\mathbf{( c m})\end{array}$ & $\begin{array}{c}\text { USG } \\
(\mathbf{c m})\end{array}$ & $\begin{array}{c}\text { ASD } \\
\mathbf{( c m})\end{array}$ & $\begin{array}{c}\text { ASG } \\
(\mathbf{c m})\end{array}$ & $\begin{array}{c}\text { PSD } \\
(\mathbf{c m})\end{array}$ & $\begin{array}{c}\text { PSG } \\
(\mathbf{c m})\end{array}$ \\
\hline Slope $\left(\mathrm{cm}^{2} / \mathrm{s}\right)$ & 0.02 & 0.06 & 0.05 & 0.05 & 0.06 & 0.04 & 0.06 \\
\hline Intercept & -1.15 & 1.03 & -0.20 & 1.48 & 0.44 & 0.95 & 0.13 \\
\hline $\mathrm{R}^{2}$ & 0.99 & 0.98 & 0.99 & 0.99 & 0.99 & 0.99 & 0.99 \\
\hline
\end{tabular}


obtained by taking logarithm of wicking height values. Thus at 0 time, there is wicking which looks absurd. Another problem with regard to this model is that when wicking height and time have values less than 1 , negative values are obtained. In this model when $K=0.5$, it is taken that Washburn's equation is valid. Alternatively, the model $h^{2}=c^{2} t$ is sound as for 0 time, 0 is the wicking [14-16]. This model is devoid of the deficiency as mentioned above.

\section{CONCLUSION}

Using the model $h^{2}=c^{2} t$ the experimental results have shown that the wicking height square had a positive and high correlation with time in the warp direction $\left(R^{2}=0.99\right)$ indicating that the Lucas Washburn's equation was suitable for evaluating the wicking property of sericin treated polyester fabrics. This other model namely, $h=c^{\prime} t^{k}$ is not sound as there are strange units.

\section{Acknowledgements}

We sincerely thank Shri Mayavan Mills Erode and Csrti Bangalore for providing the polyester fabric and sericin respectively. One of the authors dr. V. Subramaniam would like to thank prof. Jiri Militky (technical university liberec) Czech Republic for his advice.

\section{BIBLIOGRAPHY}

[1] Subramaniam, V., Pramod, Raichurkar, A review on wicking of yarn and fabrics, In: International Journal of Textile Engineering and Processing, In: 2015, vol. 1, no. 2, pp. 1-4.

[2] Deepti Gupta, Harshita Chaudhary, Charu Gupta, Sericin based bioactive coating for polyester fabric, In: Indian Journal of Fibre Textile Research, 2015, vol. 40, no. 1, pp. 70-80.

[3] Deepti Gupta, Harshita Chaudhary, Charu Gupta, Sericin-based polyester textile for medical applications, In: The Journal of the Textile Institute, 2015, vol. 106, no. 4 , pp. 366-376.

[4] Deepti Gupta, Somes Bhaumik, Antimicrobial treatments for textiles, In: Indian Journal of Fibre Textile Research, 2007, vol. 32, no. 2, pp. 254-263.

[5] Harnett, P.R., Mehta, P.N., A survey and comparison of laboratory test methods for measuring wicking, In: Textile Research Journal, 1984, vol. 54, no. 7, pp. 471-478.

[6] Saricum, C., Kalaoglu, F. Investigation of the wicking and drying behavior of polyester woven fabrics, In: Fibres \& Textile in Eastern Europe, 2014, vol. 22, no. 3, pp. 73-78.

[7] Rajagopalan, D., Aneja, A. Modeling capillary flow in complex geometries, In: Textile Research Journal, 2001, vol. 71, no. 9, pp. 813-821.

[8] Hollies, N.R.S., Kaessinger, M.M., Watson, B.S., Bogaty, H. Water transport mechanisms in textiles materials. Part II: Capillary-type penetration in yarns and fabrics, In: Textile Research Journal, 1957, vol. 27, no. 1, pp. 8-13.

[9] Loghin, C., Muresan, R., Ursache, M., Muresan, A. Surface treatments applied to textile material and implications on their behavior in wet conditions, In: Industria Textila, 2010, vol. 61, no. 6, pp. 284-290.

[10] Laughlin, R.D., Davies, J.E. Some aspects of capillary adsorption in fibrous textile wicking, In: Textile Research Journal, 1961, vol. 31, no. 10, pp. 904-910.

[11] DeBoer, J.J. The wettability of scoured and dried cotton fabrics, In: Textile Research Journal, 1980, vol. 50, no. 10, pp. 624-631.

[12] Nyoni, A.B., Brook, D. Wicking mechanism in yarns - the key to fabric wicking performance, In: The Journal of Textile Institute, 2006, vol. 97, no. 2, pp. 119-128.

[13] Zhuang, Q., Harlock, S.C., Brook, D.B. Transfer wicking mechanisms of knitted fabrics used as undergarments for outdoor activities, In: Textile Research Journal, 2002, vol. 72, no. 8, pp. 727-734.

[14] Kamath, Y.K., Hornby, S.B., Weigmann, H.D., Wilde, M.F. Wicking of spin finishes and related liquids into continuous filament yarns, In: Textile Research Journal, 1994, vol. 64, no. 1, pp. 33-40.

[15] Ansari, N., Kish, M.H. The wicking of water in yarn as measured by an electrical resistance technique, In: Journal of Textile Institute, 2000, vol. 91, no. 3, pp. 410-419.

[16] Sharabaty, T., Biquenct, F., Dupus, D., Viallier, P. Investigation on moisture transport through polyester/cotton fabrics, In: Industrial Journal Fiber Textile Research, 2008, vol. 33, no. 4, pp. 419-425.

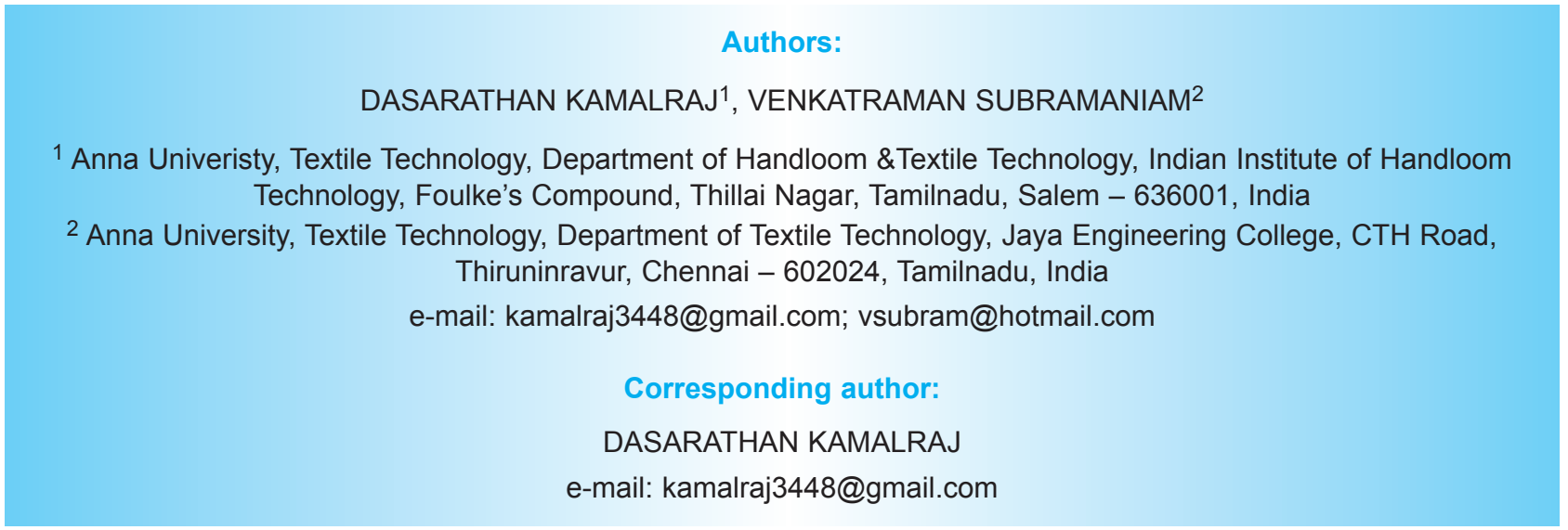

